\title{
Enterobacterial infection in Saudi Arabia: First record of Klebsiella pneumoniae with triple carbapenemase genes resistance
}

\author{
Mubashir A Khan ${ }^{1}$, Amr M Mohamed ${ }^{1,2}$, Aftab Faiz $^{3}$, Jawwad Ahmad ${ }^{1}$ \\ ${ }^{1}$ Department of Laboratory Medicine, Faculty of Applied Medical Sciences, Umm Al Qura University, Makkah, \\ Saudi Arabia \\ ${ }^{2}$ Clinical Laboratory Diagnosis, Faculty of Veterinary Medicine, Assiut University, Assiut, Egypt \\ ${ }^{3}$ Microbiology Department, Maternity and Children hospital, Makkah, Saudi Arabia
}

\begin{abstract}
Introduction: Carbapenemase producing Enterobacteriaceae are emerging as important pathogens worldwide with serious effects on patients' outcome. The study aimed to investigate the emergence of carbapenemases associated with enterobacterial infection in Western region of Saudi Arabia.

Methodology: Clinical isolates from suspected patients with enterobacterial infection were investigated over a one-year period from four tertiary care hospitals of Makkah, Saudi Arabia. All isolates were identified using Vitek-2 system and then screened for potential carbapenemase production using disk diffusion test. Suspected isolates with reduced susceptibility to carbapenems were further investigated for blanDM-1, blakPC and blaoxA-48 resistant genes.

Results: Out of 120 confirmed Enterobacteriaceae isolates, Klebsiella pneumoniae and Escherichia coli comprised the largest proportion (35\% and $34.2 \%$, respectively) of encountered infections. Twenty-six $(21.7 \%)$ isolates showed resistance to carbapenems, the majority of which (21/26) were K. pneumoniae. Remarkably, 17 isolates carried triple resistant genes KPC/NDM-1/OXA-48 while the other 4 carried double resistant genes (KPC/OXA-48) or (NDM-1/OXA-48). The current study revealed that the mentioned triple resistance genes have the higher incidence with significant association risk among males (COR 4.5; CI: 1.9-17.3; P = 0.018), non-Saudi nationalities (COR 4.9; CI: 1.5-19.3; P $=0.003)$, ICU-obtained specimens (COR 3.6; CI: 1.5-8.4; P = 0.002) and blood specimens (COR 2.8; CI: 1.1-6.9; P = 0.02).

Conclusion: Multidrug-resistant Enterobacteriaceae isolates in particular K. pneumoniae co-harboring KPC, NDM-1 and OXA-48 genes are emerging in Western region, Saudi Arabia. This is the first record of triple carbapenemase genes co-producing K. pneumoniae associated with enterobacterial infection.
\end{abstract}

Key words: Enterobacterial infection; K. pneumoniae; carbapenemase genes; KPC; NDM-1; OXA-48.

J Infect Dev Ctries 2019; 13(4):334-341. doi:10.3855/jidc.11056

(Received 25 November 2018 - Accepted 05 March 2019)

Copyright (C) 2019 Khan et al. This is an open-access article distributed under the Creative Commons Attribution License, which permits unrestricted use, distribution, and reproduction in any medium, provided the original work is properly cited.

\section{Introduction}

There has been emergence of isolates producing carbapenemases that efficiently hydrolyze carbapenems as well as most $\beta$-lactam drugs. The most common carbapenemases reported worldwide among Enterobacteriaceae are the Ambler class A Klebsiella pneumoniae carbapenemase (KPC), class B metallo- $\beta$ lactamases (VIM, IMP, NDM), and class D (OXA-48) types. These are most commonly found in $K$. pneumoniae isolates that are frequently associated with nosocomial infections and outbreaks [1].

The prevalence of carbapenemases-producing Enterobacteriaceae (KPC, NDM, OXA-48) varies significantly among different countries. The KPC has been reported worldwide but more predominantly found in the United States, Greece, South America, China and Taiwan [2]. Similarly, most of the NDM cases indicated a link with the Indian subcontinent $[3,4]$ or Balkan countries [5,6] and from Middle East region [7-11]. Whereas, the OXA-48 producing $K$. pneumoniae is endemic in Turkey, Morocco, Libya, Egypt, Tunisia [12] and has also been documented in Mediterranean region [13], Middle East [14-16] and European countries [17,18]. All three types of carbapenemases have been frequently described from India, Spain, France, Italy and United Kingdom [19]. In Arabian Peninsula, recent studies have shown the predominance of OXA-48 and NDM type carbapenemases $[11,20]$ where both OXA-48 and NDM producing K. pneumoniae were found in Oman $[7,15]$, Kuwait [8], Qatar [11] and Saudi Arabia [10,16]. Instead, the region used to be free from KPC-producing Enterobacteriaceae where no previous studies claimed their isolation. However, recently two K. pneumoniae 
carrying bla $a_{\mathrm{KPC}-2}$ were isolated from 2 local patients in United Arab Emirates (UAE) and denoted the emergence of KPC-producing strains for the first time in Arabian Peninsula [21].

Multi-drug resistant K. pneumoniae isolates usually carry a single carbapenemase (e.g., KPC, NDM, OXA48-like), however, unique and rare $K$. pneumoniae isolates co-producing two classes of carbapenemases have also been reported from Singapore [22] and countries of Europe [23,24] and Middle East [15,25]. In Saudi Arabia, the emergence of NDM- 1 or OXA-48 has also been reported in K. pneumoniae isolates, however, none of these isolates either harbored KPC gene or combination of NDM-1 and OXA-48 [16].

Considering the extensive links of Makkah to the rest of the world as a target for millions of people from all over the world, the aim of the current study was to assess the resistance profile among Enterobacteriaceae isolates and to investigate the emergence of $\mathrm{KPC}$, NDM-1 and OXA-48 resistance genes in Makkah (Western region), Saudi Arabia.

\section{Methodology}

Study Design

In a cross-sectional study, different clinical specimens were collected from suspected patients admitted to different wards of the four main tertiary care hospitals of Makkah over a period of 1 year (January 2017 to December 2017). Inclusion criteria included any suspected patient with clinical symptoms related to respiratory tract, urinary tract, gastrointestinal tract, and wound infections. Specimens from patients on antibiotic therapy were excluded from the study. A total of 864 specimens were investigated for the causative agents belonging to Enterobacteriaceae. Recovered isolates were identified using Vitek 2 compact system (BioMerieux, USA) and then screened for reduced susceptibility to carbapenems and further investigated for the presence of carbapenemases genes. In addition to type of collected specimens and admission wards, demographic information of corresponding patients including age, gender and nationality were obtained using a predesigned patient data sheet.

The medical ethics committee of Umm Al Qura University has approved the current study in accordance with the declaration of Helsinki (AMSEC 7/10-12-2016). A written consent was collected from all participating patients acknowledging the inclusion of their data anonymously in the study.
Screening for reduced susceptibility to carbapenems

All recovered Enterobacteriaceae isolates were first screened for reduced susceptibility to carbapenems by disk diffusion method using ceftazidime $(30 \mu \mathrm{g})$, cefotaxime $(30 \mu \mathrm{g})$, cefpodoxime $(10 \mu \mathrm{g})$, imipenem $(10 \mu \mathrm{g})$ and meropenem $(10 \mu \mathrm{g})$ following guidelines of Clinical and Laboratory Standards Institute (CLSI) [26]. In addition, minimum inhibitory concentration (MIC) of isolates which showed reduced susceptibility or resistance to carbapenems in screening test were determined for ceftazidime, cefotaxime, ceftriaxone, cefepime, imipenem, meropenem, amikacin, gentamicin and colistin using Gram-negative antibiotic susceptibility panel of Vitek-2 system.

\section{Detection of carbapenemases genes}

All suspected isolates of carbapenem-resistant Enterobacteriaceae (CRE) were further tested for the production of carbapenemase genes by standard PCR method. Chromosomal DNA and/or bacterial plasmid DNA was extracted from selected bacterial strains using DNeasy Blood and Tissue kit (Qiagen, Dammam, Saudi Arabia) and/or PureYield Plasmid Miniprep System (Promega Corporaon, Madison, WI, USA), respectively according to manufacturer's instructions. The bla $a_{\mathrm{NDM}-1}$ gene was detected by PCR amplification of a $758 \mathrm{bp}$-specific product using forward primer (5'GGGCCGTATGAGTGA-3') and reverse primer (5'GAAGCTGAGCACCGCATTAG-3') as described earlier by Sidjabat et al. [27]. The detection of bla gene was carried out using primer set KPC-1 (5'ATGTCACTGTATCGCCGTC-3') and KPC-2 (5'AATCCCTCGAGCGCGAGT-3') for generation of a 862 bp-specific product as previously described by Mulvey et al. [28], while primer set OXA-48A (5'TTGGTGGCATCGATTATCGG-3') and OXA-48B (5'-GAGCACTTCTTTTGTGATGGC-3') was used for detection of bla $a_{\text {OXA-48 }}$ gene by amplifying a $743 \mathrm{bp}$ specific product after Poirel et al. [29].

\section{Statistical analysis}

Statistical analysis of the results was performed using SPSS version 16 (SPSS, Chicago, IL, USA). The frequencies of CRE isolates and associated resistance genes were assessed based on gender, nationalities, type and source of specimens using cross-tabulation followed by Chi square $\left(\chi^{2}\right)$ test or Fischer's exact test. A crude odd ratio (COR) with $95 \%$ confidence interval (CI) was calculated for frequency analysis as appropriate for the assessment of possible association risk ratio between resistance genes and different factors including patient's nationality, gender, type and source 
of infection. The tests were two tailed and $\mathrm{P}$ value $<$ 0.05 was considered significant.

\section{Results}

Descriptive analysis of study population

A total of 120 cases out of 864 suspected patients were confirmed with Enterobacteriaceae infection and served as the study population. Descriptive analysis of study population is presented in Table 1 showing the frequency of investigated population in relation to gender and nationality of patients as well as type and source of collected specimens. The results revealed that the majority of Enterobacteriaceae-infected study population was of Saudi nationality $(65.8 \%)$. In term of source and type of specimens, the majority of specimens were encountered from medical ward (46.7\%) and urine specimens (44.2\%), respectively.

\section{Identification and resistance profile of} Enterobacteriaceae isolates

Klebsiella pneumoniae and Escherichia coli together comprised $69.2 \%$ of total 120 Enterobacteriaceae isolates. The remaining 30.8\% included, Serratia species (5.8\%), K. ornithinolytica and Proteus mirabilis (5\%, each), K. oxytoca and Enterobacter cloacae (4.2\%, each), Citrobacter species (3.3\%), Salmonella species $(2.5 \%)$ and E.aerogenes $(0.8 \%)$. Twenty-six isolates were resistant to the tested cephalosporins (ceftazidime, cefotaxime, ceftriaxone, cefepime) in which the MICs of the most mentioned cephalosporins and tested carbapenems were between $>$ 32-64 $\mu \mathrm{g} / \mathrm{mL}$ and $>8-16 \mu \mathrm{g} / \mathrm{mL}$, respectively. In addition, a high degree of resistance to gentamicin $(>8$ $16 \mu \mathrm{g} / \mathrm{mL})(65.3 \%)$ and amikacin $(>64 \mu \mathrm{g} / \mathrm{mL})(42.3 \%)$ were also recorded. No isolates were resistant to colistin except three strains of $P$. mirabilis, which are intrinsically resistant. The antibiotic susceptibility profile of CRE isolates in relation to organism, wards, specimens, nationality and associated carbapenemase genes (Table 1-S) and MICs of these isolates (Table 2S) was determined. Antibiotic susceptibility profiles of all recovered enterobacterial isolates were also obtained (Table 3-S).

Frequency and distribution of carbapenem resistant Enterobacteriaceae (CRE)

Twenty-six out of 120 Enterobacteriaceae isolates were identified as carbapenem resistant. High significant difference $(\mathrm{P}<0.001)$ in the frequency of carbapenem resistance was recorded among different Enterobacteriaceae species. Therefore, K. pneumonia was the most predominant strain among the others $(80.8 \%)$ and that was followed by E. coli $(7.7 \%), E$. cloacae $(7.7 \%)$ and P. mirabilis $(3.8 \%)$ as the least strains (Table 2).

The distribution of CRE according to the nationality, gender, source and types of specimens showed that K. pneumoniae was slightly higher in nonSaudis (42.3\%) compared to Saudis (38.5\%). Other CRE such as E. coli, E. cloacae and P. mirabilis were

Table 1. Descriptive analysis of study population and specimens.

\begin{tabular}{|c|c|c|c|c|c|}
\hline \multirow{3}{*}{$\begin{array}{l}\text { Population } \\
(\mathrm{n}=120)\end{array}$} & $\begin{array}{c}\text { Age (years) } \\
\text { (Min-Max) } \\
(\text { Mean } \pm \text { SD) }\end{array}$ & \multicolumn{4}{|c|}{$\begin{array}{c}\text { Nationality/Gender } \\
\text { No (\%) }\end{array}$} \\
\hline & \multirow{2}{*}{$\begin{array}{l}(0.66-91.0) \\
(24.6 \pm 49.2)\end{array}$} & \multicolumn{2}{|c|}{$\begin{array}{c}\text { Saudi } \\
79(65.8)\end{array}$} & \multicolumn{2}{|c|}{$\begin{array}{l}\text { Non-Saudi } \\
41(34.2)\end{array}$} \\
\hline & & $\begin{array}{c}\text { Male } \\
39(49.4)\end{array}$ & $\begin{array}{c}\text { Female } \\
40(50.6)\end{array}$ & $\begin{array}{c}\text { Male } \\
19(46.3)\end{array}$ & $\begin{array}{c}\text { Female } \\
22(53.7)\end{array}$ \\
\hline \multirow{15}{*}{$\begin{array}{l}\text { Specimens } \\
(\mathrm{n}=120)\end{array}$} & \multirow{6}{*}{$\begin{array}{c}\text { Source of specimens } \\
\text { No }(\%)\end{array}$} & \multicolumn{2}{|c|}{ Intensive care unit } & \multicolumn{2}{|c|}{$24(20)$} \\
\hline & & \multicolumn{2}{|c|}{ Medical ward } & \multicolumn{2}{|c|}{$56(46.7)$} \\
\hline & & \multicolumn{2}{|c|}{ Surgical ward } & \multicolumn{2}{|c|}{$23(19.2)$} \\
\hline & & \multicolumn{2}{|c|}{ Pediatric ward } & \multicolumn{2}{|c|}{$12(10.0)$} \\
\hline & & \multicolumn{2}{|c|}{ Antenatal ward } & \multicolumn{2}{|c|}{$1(0.8)$} \\
\hline & & Obstetri & ecology & \multicolumn{2}{|c|}{$3(2.5)$} \\
\hline & & \multicolumn{2}{|c|}{ Outpatient } & \multicolumn{2}{|c|}{$1(0.8)$} \\
\hline & & \multicolumn{2}{|c|}{ Blood } & \multicolumn{2}{|c|}{$24(20)$} \\
\hline & & \multicolumn{2}{|c|}{ Pus } & \multicolumn{2}{|c|}{$23(19.2)$} \\
\hline & & \multicolumn{2}{|c|}{ Stool } & \multicolumn{2}{|c|}{$5(4.2)$} \\
\hline & Type of specimens & \multicolumn{2}{|c|}{ Urine } & \multicolumn{2}{|c|}{$53(44.2)$} \\
\hline & No $(\%)$ & \multicolumn{2}{|c|}{ Sputum } & \multicolumn{2}{|c|}{$12(10)$} \\
\hline & & \multicolumn{2}{|c|}{ Endotracheal tube } & \multicolumn{2}{|c|}{$1(0.8)$} \\
\hline & & \multicolumn{2}{|c|}{ Vaginal swab } & \multicolumn{2}{|c|}{$1(0.8)$} \\
\hline & & \multicolumn{2}{|c|}{ Peritoneal fluid } & \multicolumn{2}{|c|}{$1(0.8)$} \\
\hline
\end{tabular}


Table 2. Frequency of resistant genes in carbapenem-resistant Enterobacteriaceae.

\begin{tabular}{|c|c|c|c|c|c|c|}
\hline \multirow{2}{*}{$\begin{array}{c}\text { Carbapenem-resistant } \\
\text { Enterobacteriaceae } \\
(\mathbf{n}=\mathbf{2 6})\end{array}$} & \multicolumn{6}{|c|}{ Resistant gene(s) } \\
\hline & $\begin{array}{c}\text { Triple } \\
\text { KPC/ NDM-1/ OXA-48 }\end{array}$ & NDM1/ OXA-48 & $\begin{array}{l}\text { Double } \\
\text { KPC/ OXA-48 }\end{array}$ & Total & $\begin{array}{c}\text { Single } \\
\text { OXA-48 }\end{array}$ & Total \\
\hline K. pneumoniae & $17(65.4)^{a}$ & $2(7.7)$ & $2(7.7)$ & $4(15.4)$ & $0(0)$ & $21(80.8)^{b}$ \\
\hline E. cloacae & $0(0)$ & $1(3.8)$ & $0(0)$ & $1(3.8)$ & $1(3.8)$ & $2(7.7)$ \\
\hline E. coli & $0(0)$ & $1(3.8)$ & $0(0)$ & $1(3.8)$ & $1(3.8)$ & $2(7.7)$ \\
\hline P. mirabilis & $0(0)$ & $1(3.8)$ & $0(0)$ & $1(3.8)$ & $0(0)$ & $1(3.8)$ \\
\hline Total & $17(65.4)^{c}$ & $5(19.2)$ & $2(7.7)$ & $7(26.9)$ & $2(7.7)$ & $26(100)$ \\
\hline
\end{tabular}

${ }^{a}$ Significantly higher frequency $(\mathrm{P} \leq 0.001)$ of triple gene resistance in K. pneumoniae isolates as compared to other types of isolates; ${ }^{b}$ Significantly higher frequency $(\mathrm{P} \leq 0.001)$ of overall gene resistance in K. pneumoniae isolates as compared to other types of isolates; ${ }^{c}$ Significantly higher frequency $(\mathrm{P}=0.001)$ of triple gene resistance among all isolates as compared to double and single gene resistance.

recovered only from Saudi patients. In relation to gender, CRE isolates were more predominant in males $(65 \%)$ compared to females $(34.6 \%)$. Similarly, carbapenem-resistant $K$. pneumoniae isolates were also more predominant in males (50\%) compared to females $(30.8 \%)$. With regard to wards, the majority of CRE isolates were from ICU $(53.9 \%)$, followed by medical $(26.9 \%)$, surgical $(11.5 \%)$ and pediatric $(7.7 \%)$ wards. It was also revealed that $46.2 \%$ of resistant isolates recovered from ICU were $K$. pneumoniae compared to $23.1 \%$ from medical ward. Regarding to the type of specimens, a substantial number of CRE strains were isolated from blood (34.6\%), followed by urine (23.1\%), pus (19.2\%) and sputum (15.5\%) specimens. The only bacterium isolated from blood specimens was $K$. pneumoniae, which was also predominantly recovered from urine (19.2\%) and sputum (15.5\%).

\section{Carbapenem resistance-associated genes}

Molecular analysis of all $26 \mathrm{CRE}$ isolates for carbapenemase genes revealed the presence of three known respective genes $b l a_{\mathrm{NDM}-1}$ (Figure 1), $b l a_{\mathrm{KPC}}$ (Figure 2) and bla $a_{\text {OXA-48 }}$ (Figure 3). All 26 isolates were found positive for OXA-48, while the majority $(24 / 26)$

Figure 1. Representative 1\% agarose gel showing positive and negative results of NDM resistance based on the amplification of corresponding bla bp Ladder; lanes 2,4,5,6,7: representative positive samples showing specific $758 \mathrm{bp}$ product; lanes 1, 3: representative negative strains showing no product and lane 8: negative control.

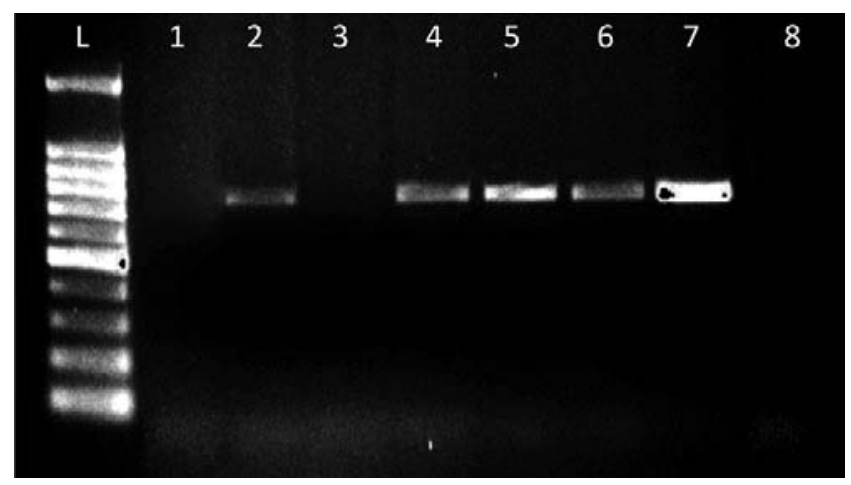

had combination of carbapenemase genes. Significantly higher frequency $(\mathrm{P}<0.000)$ of overall gene resistance was seen in K. pneumoniae isolates as compared to the other enterobacterial isolates. Out of 21 carbapenemresistant $K$. pneumoniae isolates, 17 had triple gene resistance (KPC/NDM-1/OXA-48), and 4 had double gene resistance ( 2 isolates KPC/OXA-48 and 2 isolates

Figure 2. Representative 1\% agarose gel showing positive and negative results of KPC resistance of all investigated isolates based on the amplification of corresponding bla $\mathrm{KPC}_{\mathrm{KP}}$ gene. L, 100 bp Ladder; lanes 1, 2,4,5,7: representative positive strains showing specific 862 bp product; lanes 3,6: representative negative strains showing no product and lane 8 : negative control.

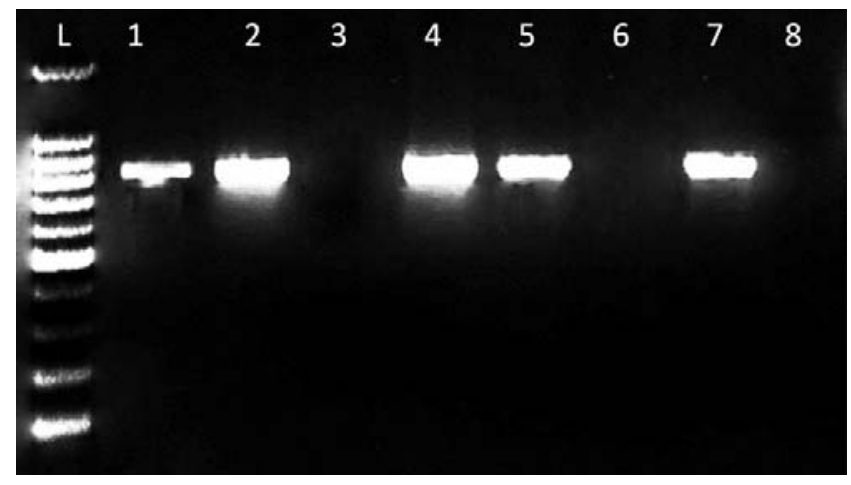

Figure 3. Representative 1\% agarose gel showing positive results of OXA-48 resistance of all investigated isolates based on the amplification of corresponding $b l a_{\text {OXA-48 }}$ gene. L, $100 \mathrm{bp}$ Ladder; lanes 1-13: representative positive strains showing specific 743 bp product and lane 14: negative control.

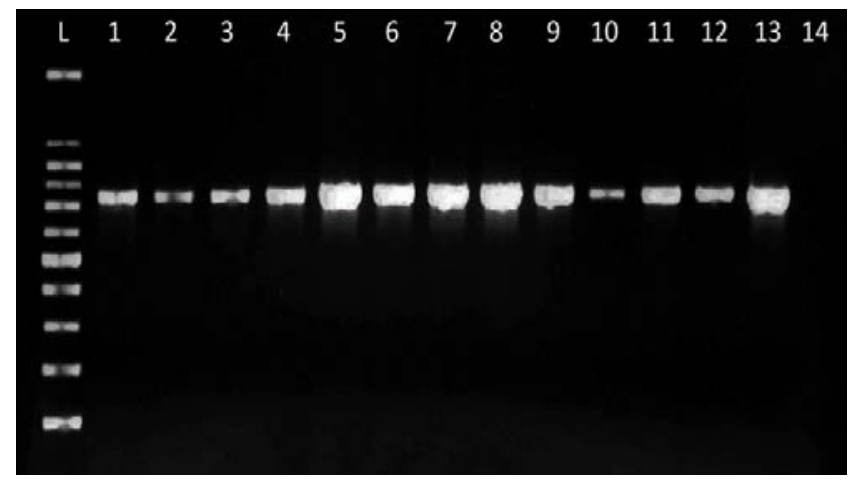


NDM-1/OXA-48). With regard to the other enterobacterial species, out of 2 isolates of both $E$. coli and E. cloacae, one isolate of each organism had combined resistant genes (NDM-1/ OXA-48) while the other isolates of each organism had only OXA-48 gene. In addition, single isolate of $P$. mirabilis carried the combined genes (NDM-1/OXA-48) (Table 2). Among all resistant isolates, triple gene resistance showed high significant frequency $(\mathrm{P}=0.001)$ compared to double or single gene resistance. Moreover, triple gene resistance was the highest among $K$. pneumoniae isolates $(\mathrm{P}<0.001)$ as compared to other enterobacterial isolates. (Table 2).

\section{Triple gene resistance in K. pneumoniae isolates}

The frequency and association risk of triple genes resistance in $K$. pneumoniae isolates in relation to nationality and gender of patients as well as type and source of specimens are shown in Table 3 . With regards to gender, significant higher frequency $(\mathrm{P}=0.028)$ was seen among male as compared to female patients with a significant association risk (COR 4.5; CI: 1.9-17.3; $P=$ $0.018)$. Similarly, significant higher frequency $(\mathrm{P}=$ 0.0001) of triple gene resistance was evident among non-Saudi as compared to Saudi patients with a significant association risk (COR 4.9; CI: 1.5-19.3; $P=$ $0.003)$. On the other hand, triple gene resistance showed significant higher frequency $(\mathrm{P}=0.004)$ in ICUobtained specimens as compared to the other sources with a significant association risk (COR 3.6; CI: 1.5$8.4 ; P=0.002)$. With regard to specimen type, triple gene resistance showed significant higher frequency $(\mathrm{P}$
$=0.001$ and $\mathrm{P}=0.04$ ) in blood specimen as compared to pus/sputum and urine, respectively with a significant association risk (COR 2.8; CI: 1.1-6.9; $P=0.02$ ). No significant association pattern was evident between patients hospitalized in the same hospital/ward (Table 4-S).

\section{Discussion}

The emerging trends in global distribution of carbapenem resistant strains have intensified the need for regular surveillance of CRE in the region of Arabian Peninsula. The current study investigated the distribution and possible emergence of carbapenemases in Enterobacteriaceae isolates and its possible associated risk factors in Makkah, Western region, Saudi Arabia. The current study revealed $K$. pneumoniae as the most predominant $(80.8 \%)$ resistant organism, which was almost equally distributed between Saudi and non-Saudi patients. Resistance in $K$. pneumoniae represents a considerable problem in the healthcare [1] and is mostly due to production of KPC that more frequently encountered in United States, Greece, South America and China [2]. In Saudi Arabia, although carbapenem resistance remained uncommon among Enterobacteriaceae, the first outbreak of carbapenem-resistant $K$. pneumoniae was reported in 2010 [30]. Later, the molecular basis of this resistance was found to be due to the involvement of OXA-48 in combination with CTX-M-15 genes [31]. Further studies detected OXA-48 and NDM-1 in carbapenem resistant $K$. pneumoniae isolates from Riyadh, Central region of Saudi Arabia [10,16]. However, isolated

Table 3. Incidence of triple genes among K. pneumoniae in relation to patient gender, specimen type and source.

\begin{tabular}{|c|c|c|c|c|}
\hline \multirow{2}{*}{ Variables } & & \multicolumn{3}{|c|}{$\begin{array}{c}\text { Incidence of Triple genes } \\
\text { No. }(\%)\end{array}$} \\
\hline & & $\begin{array}{c}\text { Saudi } \\
(\mathbf{n}=\mathbf{2 7})\end{array}$ & $\begin{array}{l}\text { Non-Saudi } \\
(n=15)\end{array}$ & $\begin{array}{c}\text { Total } \\
(n=42)\end{array}$ \\
\hline \multirow{3}{*}{ Gender } & Male & $5(18.5)$ & $7(46.6)$ & $12(28.6)^{a}$ \\
\hline & Female & $1(3.7)$ & $4(26.7)$ & $5(11.9)$ \\
\hline & Total & $6(22.2)$ & $11(73.3)^{b}$ & $17(40.5)$ \\
\hline \multirow{4}{*}{ Specimen source } & Intensive care unit & $2(7.4)$ & $7(46.7)^{c}$ & $9(21.4)^{d}$ \\
\hline & Medical ward & $3(11.1)$ & $2(13.3)$ & $5(11.9)$ \\
\hline & Surgical ward & 0 & $2(13.3)$ & $2(4.8)$ \\
\hline & Pediatric ward & $1(3.7)$ & 0 & $1(2.4)$ \\
\hline \multirow{4}{*}{ Specimen type } & Blood & $2(7.4)$ & $5(33.3)^{e}$ & $7(16.7)^{f, g}$ \\
\hline & Pus & 0 & $2(13.3)$ & $2(4.8)$ \\
\hline & Urine & $3(11.1)$ & $2(13.3)$ & $5(11.9)$ \\
\hline & Sputum & $1(3.7)$ & $2(13.3)$ & $3(7.1)$ \\
\hline \multicolumn{5}{|c|}{$\begin{array}{l}\bar{a} \text { Significant higher frequency }(\mathrm{P}=0.028) \text { among male as compared to female patients with significant association risk (COR 4.5; CI:1.97-17.265; } \mathrm{P}=0.018) ; \\
\left.{ }^{b} \text { Significant higher frequency }(\mathrm{P}=0.0001) \text { among non-Saudi as compared to Saudi patients with significant association risk (COR 4.9; CI: } 1.5-19.3 ; \mathrm{P}=0.003\right) ; \\
{ }^{c} \text { Significant higher frequency }(\mathrm{P}<0.0000) \text { in ICU obtained specimens as compared to other sources among non-Saudi patients; }{ }^{d} \text { Significant higher frequency } \\
(\mathrm{P}=0.004) \text { in ICU obtained specimens as compared to other sources among all patients with significant association risk (COR } 3.6 ; 1.5-8.4 ; P=0.002) ;{ }^{e} \\
\text { Significant higher frequency }(\mathrm{P}=0.001) \text { in blood specimens as compared to other specimen types among non-Saudi patients; }{ }^{f, g} \text { Significant higher frequency } \\
(\mathrm{P}=0.001) \text { in blood specimen as compared to pus and sputum and }(\mathrm{P}=0.04) \text { as compared to urine, respectively with significant association risk (COR } 2.8 ; \mathrm{CI} \text { : } \\
1.1-6.9 ;(P=0.02) \text { in all patients. }\end{array}$} \\
\hline
\end{tabular}


strains neither harbored KPC resistant gene nor a combination of OXA-48 and NDM-1 genes [16]. The current study is the first to characterize the molecular basis of carbapenem resistance in Makkah, Western region of Saudi Arabia. In addition to reporting NDM and OXA-48-producing Enterobacteriaceae isolates, the current study also reported KPC-producing $K$. pneumoniae for the first time in Saudi Arabia. Moreover, this interesting finding represents the second record of KPC-producing K. pneumoniae in the Arabian Peninsula next to UAE [20].

Although rare, $K$. pneumoniae isolates producing combination of carbapenemase genes, such as NDM-1 and OXA-48 or NDM-1 and OXA-181 have been reported from Singapore and European and Middle East countries [15,22-25]. To the best of our knowledge, no previous studies have reported the co-existence of the triple carbapenemase genes in K. pneumoniae isolates. Remarkably, the current study not only reported the presence of double genes, NDM-1/OXA-48, in Enterobacteriaceae isolates, but also proved the presence of the 3 known carbapenem-resistant genes (KPC/NDM/OXA-48) in K. pneumoniae isolates from Makkah region for the first time.

Presence of the triple resistance genes, as revealed in the current study, was most predominant with a significant high frequency $(\mathrm{P}=0.001)$ as compared to either double or single gene resistance among all CRE isolates. Interestingly, all cases of triple resistance genes were only reported in $K$. pneumoniae isolates (Table 2) with a significantly higher frequency ( $\mathrm{P}=$ $0.0001)$ among non-Saudi patients (73.3\%) as compared to Saudi patients $(22.2 \%)$ (Table 3). One possible explanation of these findings could be attributed to the setting of the current study, which were conducted for the first time in Makkah region. In other words, the emergence of these resistant strains could be linked to the exceptional diversity of the population of the study setting. Makkah is a unique place in Saudi Arabia and the entire world. It annually receives more than three million pilgrims during the pilgrimage season, in addition to several other millions of visitors during the whole year $[32,33]$. The fact that many of those visitors and foreign residents come from endemic carbapenem resistant or high-incidence countries as India, Pakistan, Far East and Middle East [2,5,6,21] extremely increase the risk for emerging of new multidrug resistant strains from all over the world.

The antibiotic susceptibility profile of our isolates is similar to those reported from multidrug-resistant organisms harboring carbapenemase genes from the countries of the Middle East e.g., Kuwait [8], Lebanon
[9], Saudi Arabia [16], UAE [34] and also other countries; e.g., USA [35] and China [36]. Some of the KPC-producing $K$. pneumoniae strains remain susceptible to gentamicin, but this is not the case for NDM- producing Enterobacteriaceae strains as many of which produce $16 \mathrm{~S}$ ribosomal RNA methyltransferase that makes them highly resistant to all aminoglycosides including gentamicin. Though OXA-48 itself does not hydrolyze cephalosporins efficiently, OXA-48-producing K. pneumoniae strains appear to co-produce ESBL in most instances, therefore, they are resistant to cephalosporins as well as carbapenems [19]. This phenomenon has been observed by many investigators where multi-drug resistant isolates are often associated with carbapenemase production [15,35-36].

In our study, frequency and risk association to the triple resistance genes in $K$. pneumoniae isolates were significantly evident among overall male patients (COR 4.5; CI: $1.9-17.3 ; P=0.018)$ as compared to female patients and was also evident among non-Saudi (COR 4.9; CI: $1.5-19.3 ; P=0.003$ ) as compared to Saudi patients. This could be linked to the population travelling to Saudi Arabia either for the employment or Islamic rituals in particular to Makkah throughout the year from countries known as common reservoirs for carbapenemase producing (NDM, OXA-48 and KPC) Enterobacteriaceae [6,13]. These factors greatly increase the risk of emerging new multidrug resistant strains, which make Makkah highly exposed to the spread of various infectious agents including CRE. On the other hand, the current study also revealed that the majority of the K. pneumoniae isolates carrying triple genes were isolated from blood specimens with a significant risk association (COR 2.8; CI: 1.1-6.9; $P=$ 0.02 ) as compared to the other types of specimens collected from ICU patients (COR 3.6; CI: 1.5-8.4; $P=$ 0.002 ) and other wards. These findings draw the attention towards nosocomial infections as a possible source of dissemination of these resistance strains among critically ill patients. Similar findings have been reported in a study from Riyadh, Saudi Arabia, where K. pneumoniae harboring NDM genes were isolated from ICU patients [16].

At present, it is difficult to predict whether the occurrence of these carbapenemases-producing $K$. pneumoniae isolates is due to population movement or local emergence of these strains, in particular KPCpositive $K$. pneumoniae, which has not been reported earlier from Saudi Arabia. Interestingly, previous studies from Arabian Peninsula reported that CRE infections are not limited to foreign exposure. It was 
shown that the majority of reported cases had no history of foreign travel or hospitalization abroad [7,8,10,15]. In UAE, a recent study showed that lack of foreign exposure was more common in OXA-48-like carbapenemase producing and VIM positive strains where the majority of these strains appeared to be acquired locally. On the other hand, previous hospitalization abroad (mostly in India) could represent a risk factor for acquisition of NDM-1 gene [35]. Thus, the currently isolated triple genes-producing $K$. pneumoniae may suggest that in addition to international travel exposure, indigenous transmission could be a major factor for the emergence of those strains as well.

In the current study, certain limitations were evident including the lack of international travel and/or foreign hospitalization history of the investigated patients. Another limitation is the lack of efficient admission screening and information about the history of patients whether they were carrying carbapenemase-producing pathogen at the time of admission or were nosocomial acquisition. Indeed, further epidemiologic and genotypic investigations are needed to be conducted to unveil the curiosity behind the multiple genes-based resistance and to trace the source of these emerging extraordinary resistant isolates.

\section{Conclusion}

This study documents the ongoing emergence of carbapenemase genes (KPC, NDM-1 and OXA-48) and in particular the coexistence of these genes in $K$. pneumoniae strains. These resistant isolates showed significant risk association with the male gender (COR 4.5; CI: $1.9-17.3 ; P=0.018)$ and non-Saudi nationality (COR 4.9; CI: 1.5-19.3; $P=0.003$ ) as well as blood specimens (COR 2.8; CI: 1.1-6.9; $P=0.02$ ) of ICU patients (COR 3.6; CI: 1.5-8.4; $P=0.002$ ). Such isolates can have significant public health importance as these may combine a variety of resistance attributes that make them nearly untreatable. Therefore, there is a need to extend the awareness among healthcare providers in the countries. Additionally, improved national surveillance mechanisms for the detection of these multidrug-resistant pathogens will help to take appropriate infection control measures in order to curtail further dissemination of these life-threatening pathogens. At the same time, close cooperation between the countries of the region is required to control the dissemination across borders.

\section{References}

1. Nordmann P, Naas T, Poirel L (2011) Global spread of carbapenemase-producing Enterobacteriaceae. Emerg Infect Dis 17: 1791-1798.

2. Tzouvelekis LS, Markogiannakis A, Psichogiou M, Tassios PT, Daikos GL (2012) Carbapenemases in Klebsiella pneumoniae and other Enterobacteriaceae: an evolving crisis of global dimensions. Clin Microbiol Rev 25: 682-707.

3. Yong D, Toleman MA, Giske CG, Cho HS, Sundman K, Lee K, Lee K, Walsh TR (2009) Characterization of a new metallobeta-lactamase gene, bla(NDM-1), and a novel erythromycin esterase gene carried on a unique genetic structure in Klebsiella pneumoniae sequence type 14 from India. Antimicrob Agents Chemother 253: 5046-5054.

4. Kumarasamy KK, Toleman MA, Walsh TR, Bagaria J, Butt F, Balakrishnan R, Chaudhry U, Doumith M, Giske CG, Irfan S, Krishan P, Kumar AV, Maharajan S, Mushtaq S, Noorie T, Paterson D, Pearson A, Perry C, Pike R, Rao B, Ray U, Sarma JB, Sharma M, Sheridon E, Thirunarayan MA, Turton J, Upadhyay S, Warner M, Welfare W, Livermore DM, Woodford N (2010) Emergence of a new antibiotic resistance mechanism in India, Pakistan, and the UK: a molecular, biological, and epidemiological study. Lancet Infect Dis 10: 597-602.

5. Nordmann P, Poirel L, Walsh TR, Livermore DM (2011) The emerging NDM carbapenemases. Trends Microbiol 19: 588595.

6. Dortet L, Poirel L, Nordmann P (2014) Worldwide dissemination of the NDM-type carbapenemases in Gramnegative bacteria. Biomed Res Int Article ID 249856.

7. Poirel L, Al Maskari Z, Al Rashdi F, Bernabeu S, Nordmann P (2011) NDM-1-producing Klebsiella pneumoniae isolated in the Sultanate of Oman. J Antimicrob Chemother 66:304-6.

8. Jamal WY, Albert MJ, Rotimi VO (2016) High prevalence of New Delhi metallo- $\beta$-lactamase-1 (NDM-1)-producers among carbapenem-resistant Enterobacteriaceae in Kuwait. PloS ONE 11: e0152638.

9. El-Herte RI, Araj GF, Matar GM, Baroud M, Kanafani ZA, Kanj SS (2012) Detection of carbapenem-resistant Escherichia coli and Klebsiella pneumoniae producing NDM-1 in Lebanon (case report). J Infect Dev Ctries 6: 457-461. doi: $10.3855 /$ jidc. 2340

10. Al-Agamy MH, Shibl AM, Elkhizzi NA, Meunier D, Turton JF, Livermore DM (2013) Persistence of Klebsiella pneumoniae clones with OXA-48 or NDM carbapenemases causing bacteraemias in a Riyadh hospital. Diagn Microbiol Infect Dis 76: 214-216.

11. Zowawi HM, Sartor AL, Balkhy HH, Walsh TR, Al Johani SM, AlJindan RY, Alfaresi M, Ibrahim E, Al-Jardani A, AlAbri S, Al-Salman J, Dashti AA, Kutbi AH, Schlebusch S, Sidjabat HE, Paterson DL (2014) Molecular characterization of carbapenemase producing Escherichia coli and Klebsiella pneumoniae in the countries of the Gulf Cooperation Council: dominance of OXA-48 and NDM producers. Antimicrob Agents Chemother 58: 3085-3090.

12. Nordmann P, and Poirel I (2014) The difficult-to control of carbapenemase producers among Enterobacteriaceae worldwide. Microbiol Infect 20: 821-830.

13. Poirel L, Potron A, Nordmann P (2012) OXA-48-like carbapenemases: the phantom menace. J Antimicrob Chemother 67:1597-1606.

14. Matar GM., Dandache I, Carrier A, Khairallah, MT., Nordamnn, P, Sabra A, Araj GF (2010) Spread of OXA-48- 
medited resistance to carbapenems in Lebanese Klebsiella pneumoniae and Escherichia coli that produce extended spectrum $\beta$-lactamase. Ann Trop Med Parasitol 104: 271-274

15. Dortet L, Poirel L, Al Yaqoubi F, Nordmann P (2012) NDM1, OXA-48 and OXA-181 carbapenemase-producing Enterobacteriaceae in Sultanate of Oman. Clin Microbiol Infect 18: E144-148.

16. Shibl A, Al-Agamy M, Memish Z, Senok A, Khader SA, Assiri A (2013) The emergence of OXA-48- and NDM-1-positive Klebsiella pneumoniae in Riyadh, Saudi Arabia. Int J Infect Dis 17: e1130-1133.

17. Cuzon G, Ouanich J, Gondret R, Naas T, Nordman P (2011) Outbreak of OXA-48-positive carbapenem-resistant Klebsiella pneumoniae isolates in France. Antimicrob Agents Chemother 55: 2420-2423.

18. Pfeifer Y, Schlatterer K, Engelmann E, Schiller RA, Frangenberg HR, Stiewe D, Holfelder M, Witte W, Nordman P, Poirel L (2012) Emergence of OXA-48-type carbapenemase-producing Enterobacteriaceae in German hospitals. Antimicrob Agents Chemother 56: 2125-2128.

19. Lee CR, Lee JH, Park KS, Kim YB, Jeong BC, Lee SH (2016) Global dissemination of carbapenemase-producing Klebsiella pneumoniae: Epidemiology, genetic context, treatment options, and detection methods. Frontiers in Microbiology 7: 895

20. Doi Y, Paterson DL (2015) Carbapenemase-producing Enterobacteriaceae. Semin Respir Crit Care Med 36: 74-84.

21. Sonnevend A, Ghazawi A, Darwish D, AlDeesi Z, Kadhum AF, Pal T (2015) Characterization of KPC-type carbapenemase-producing Klebsiella pneumoniae strains isolated in the Arabian Peninsula. J Antimicrob Chemother 70: 1592-1593

22. Balm MND, La MV, Krishan P, Jureen R, Lin RTP, Teo JWP (2013) Emergence of Klebsiella pneumoniae co-producing NDM-type and OXA-181carbapenemases. Clin Microbiol Infect 19: E421-423.

23. Samuelsen O, Naseer U, Karah N, Lindemann PC, Kanestrom A, Leegard TM, Sundsfjord A (2013) Identification of Enterobacteriaceae isolates with OXA-48 and coproduction of OXA-181 and NDM-1 in Norway. J Antimicrob Chemother 68: 1682-1685.

24. Seiffert SN, Marschall J, Perreten V, Carattoli A, Furrer H, Endimiani A (2014) Emergence of Klebsiella pneumoniae coproducing NDM-1, OXA-48, CTX-M-15, CMY-16, QnrA and ArmA in Switzerland. Int J Antimicrob Agents 44: 260-262.

25. Nasr AB, Decre D, Compain F, Genel N, Barguellil F, Arlet G (2013) Emergence of NDM-1 in association with OXA-48 in Klebsiella pneumoniae from Tunisia. Antimicrob Agents Chemother 57: 4089-4090.

26. CLSI (2012) Performance standards for antimicrobial susceptibility testing; Twenty-second informational supplement. M100-S22: 32(3). Wayne Pennsylvania: Clinical Laboratory Standards Institute

27. Sidjabat H, Nimmo GR, Walsh TR, Binotto E, Htin A, Hayashi Y, Li J, Nation RL, George N, Paterson DL (2011) Carbapenem resistance in Klebsiella pneumoniae due to the New Delhi metallo-ß-lactamase. Clin Infect Dis 52: 481-484.
28. Mulvey MR, Grant JM, Plewes K, Roscoe D, Boyd DA (2011) New Delhi metallo- $\beta$-Lactamase in Klebsiella pneumoniae and Escherichia coli, Canada. Emerg Infect Dis 17: 103-106.

29. Poirel L, Heritier C, Tolun V, Nordmann P (2004) Emergence of oxacillinase-mediated resistance to imipenem in Klebsiella pneumonia. Antimicrob Agents Chemother 48: 15-22.

30. Balkhy HH, El-Saed A, Al Johani SM, Francis C, Al-Qahtani AA, Al-Ahdal MN, Altayab HT, Arabi Y, Alothman A, Sallah M (2012) The epidemiology of the first described carbapenemresistant Klebsiella pneumoniae outbreak in a tertiary care hospital in Saudi Arabia: how far do we go? Eur J Clin Microbiol Infect Dis.31: 1901-1909.

31. Zaman TU, Aldrees M, Al Johani SM, Alrodayyan M, Aldughashem FA, Balkhy HH, (2014) Multi-drug carbapenem-resistant Klebsiella pneumoniae infection carrying the OXA-48 gene and showing variations in outer membrane protein 36 causing an outbreak in a tertiary care hospital in Riyadh, Saudi Arabia. Int J Infect Dis 28: 186-192.

32. Al-Jasser FS, Kabbash IA, Almazroa MA, Memish ZA (2012) Patterns of diseases and preventive measures among domestic hajjis from Central, Saudi Arabia. Saudi Med J. 33: 879-886.

33. Shujaa A, Alhamid S (2015) Health response to Hajj mass gathering from emergency perspective, narrative review. Turk J Emerg Med 15: 172-176.

34. Sonnevend A, Ghazawi AA, Hashmey R, Jamal W, Rotimi VO, Shibl AM, Al-Jardani A, Al-Abri SS, Tariq WUZ, Weber S, Pal T (2015) Characterization of carbapenem-resistant Enterobacteriaceae with high rate of autochthonous transmission in the Arabian Peninsula. PLoS ONE 10: $\mathrm{e} 0131372$

35. Rasheed JK, Kitchel B, Zhu W, Anderson KF, Clark NC, Ferraro MJ, Savard P, Humphries RM, Kallen AJ, Limbago BM (2013) New Delhi metallo- $\beta$-lactamase-producing Enterobacteriaceae, United States. Emerg Infect Dis 19: 870878.

36. Wang X, Chen G, Wu X, Wang L, Cai J, Chan EW, Chen S, Zhang R (2015) Increased prevalence of carbapenem resistant Enterobacteriaceae in hospital setting due to cross-species transmission of the blaNDM-1 element and clonal spread of progenitor resistant strains. Front Microbiol 6: 595.

\section{Corresponding author}

Mubashir Ahmad Khan

Professor of Microbiology

Department of Laboratory Medicine

Faculty of Applied Medical Sciences

Umm Al Qura University

P.O. Box. 7607

Makkah, Saudi Arabia

Tel: 00-966-509010825

Fax: 00-966-12-5270000-Ext-2727

Email: mubashirpmrc@yahoo.com

Conflict of interests: No conflict of interests is declared. 


\section{Annex - Supplementary Items}

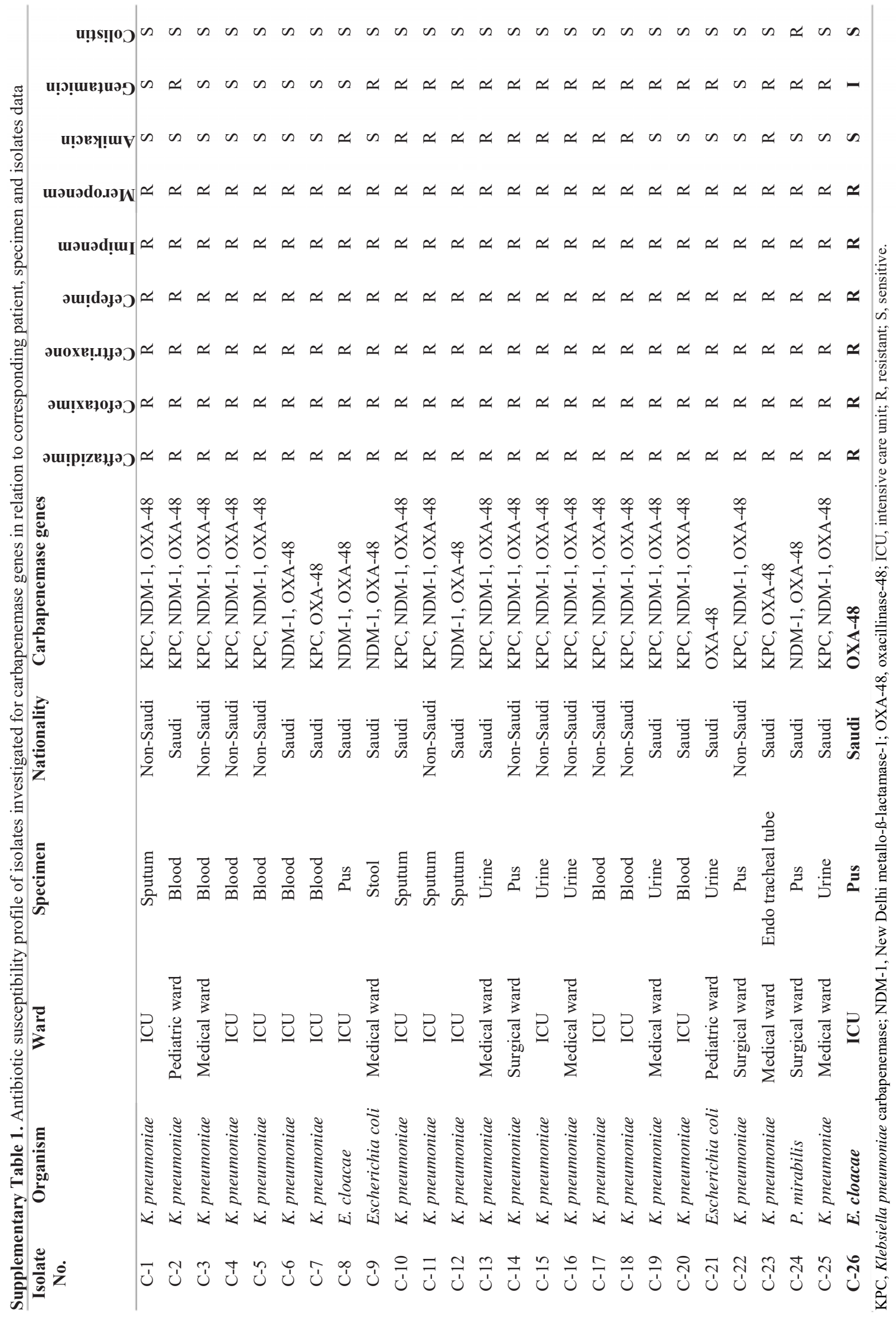




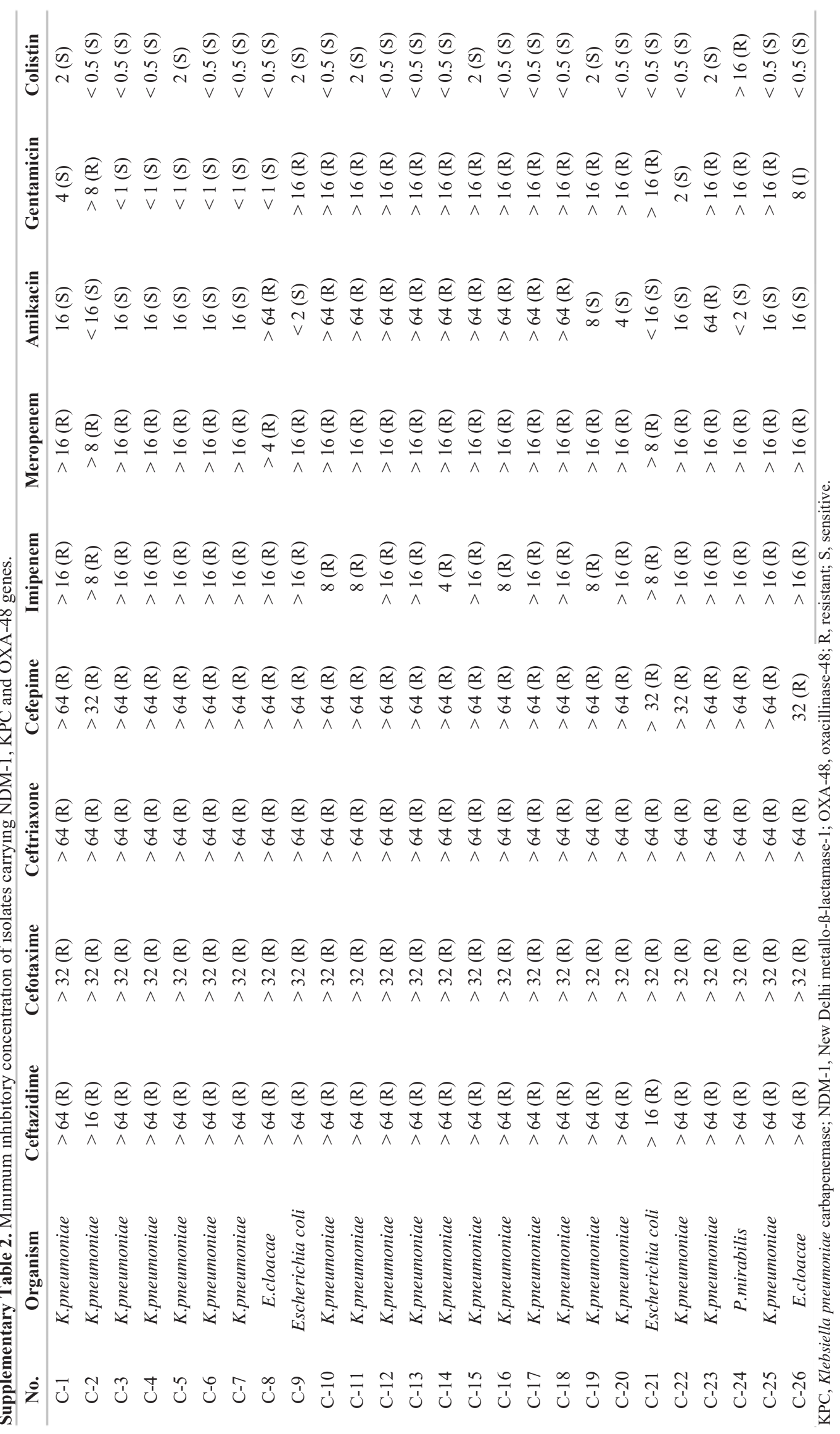


Supplementary Table 3. Antibiotic susceptibility profile of all investigated Enterobacteriaceae strains from participating hospitals $(\mathrm{n}=120)$.

\begin{tabular}{|c|c|c|c|c|c|c|c|c|c|c|c|c|}
\hline $\begin{array}{l}\text { S. } \\
\text { No }\end{array}$ & $\underset{* *}{\text { Hospital code No }}$ & Organism & Carbapenemase genes & 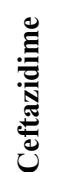 & 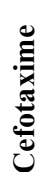 & 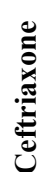 & $\frac{\mathscr{\Xi}}{\frac{\pi}{2}}$ & 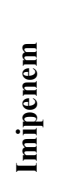 & 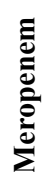 & 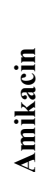 & 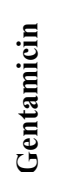 & 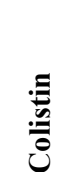 \\
\hline 1 & B-558 (C4) & K. pneumoniae & KPC, NDM-1, OXA-48 & $\mathrm{R}$ & $\mathrm{R}$ & $\mathrm{R}$ & $\mathrm{R}$ & $\overrightarrow{\mathrm{R}}$ & $\mathrm{R}$ & $\mathrm{S}$ & $\mathrm{S}$ & $\mathrm{S}$ \\
\hline 2 & $\mathrm{~B}-590(\mathrm{C} 5)$ & K. pneumoniae & KPC, NDM-1, OXA-48 & $\mathrm{R}$ & $\mathrm{R}$ & $\mathrm{R}$ & $\mathrm{R}$ & $\mathrm{R}$ & $\mathrm{R}$ & $\mathrm{S}$ & $\mathrm{S}$ & $\mathrm{S}$ \\
\hline 3 & B-1036 (C6) & K. pneumoniae & NDM-1, OXA-48 & $\mathrm{R}$ & $\mathrm{R}$ & $\mathrm{R}$ & $\mathrm{R}$ & $\mathrm{R}$ & $\mathrm{R}$ & $\mathrm{S}$ & $\mathrm{S}$ & $\mathrm{S}$ \\
\hline 4 & B-43 & E. cloacae & --- & $\mathrm{R}$ & $\mathrm{R}$ & $\mathrm{R}$ & $\mathrm{R}$ & $\mathrm{S}$ & $\mathrm{S}$ & $\mathrm{S}$ & $\mathrm{R}$ & S \\
\hline 5 & B- 880 & Escherichia coli & --- & I & $\mathrm{R}$ & $\mathrm{R}$ & I & $\mathrm{S}$ & $\mathrm{S}$ & $\mathrm{S}$ & $\mathrm{R}$ & S \\
\hline 6 & B-44 & E. cloacae & --- & $\mathrm{R}$ & $\mathrm{R}$ & $\mathrm{R}$ & $\mathrm{R}$ & $\mathrm{S}$ & $\mathrm{S}$ & $\mathrm{R}$ & $\mathrm{S}$ & S \\
\hline 7 & B-1004 & Escherichia coli & --- & $\mathrm{S}$ & $\mathrm{R}$ & I & $\mathrm{S}$ & $\mathrm{S}$ & $\mathrm{S}$ & $\mathrm{S}$ & $\mathrm{S}$ & $\mathrm{S}$ \\
\hline 8 & $\mathrm{~B}-1041(\mathrm{C} 7)$ & K. pneumoniae & KPC, OXA-48 & $\mathrm{R}$ & $\mathrm{R}$ & $\mathrm{R}$ & $\mathrm{R}$ & $\mathrm{R}$ & $\mathrm{R}$ & $\mathrm{S}$ & $\mathrm{S}$ & $\mathrm{S}$ \\
\hline 9 & B-5048 (C26) & E. cloacae & OXA-48 & $\mathrm{R}$ & $\mathrm{R}$ & $\mathrm{R}$ & $\mathrm{R}$ & $\mathrm{R}$ & $\mathrm{R}$ & $\mathrm{S}$ & I & S \\
\hline 10 & B-5056 & K. pneumoniae & --- & $\mathrm{R}$ & $\mathrm{R}$ & $\mathrm{R}$ & $\mathrm{R}$ & $\mathrm{S}$ & $\mathrm{S}$ & $\mathrm{S}$ & $\mathrm{R}$ & $\mathrm{S}$ \\
\hline 11 & $\mathrm{~B}-28(\mathrm{C} 3)$ & K. pneumoniae & KPC, NDM-1, OXA-48 & $\mathrm{R}$ & $\mathrm{R}$ & $\mathrm{R}$ & $\mathrm{R}$ & $\mathrm{R}$ & $\mathrm{R}$ & $\mathrm{S}$ & $\mathrm{S}$ & $\mathrm{S}$ \\
\hline 12 & B-443 & Escherichia coli & --- & $\mathrm{R}$ & $\mathrm{R}$ & $\mathrm{R}$ & $\mathrm{R}$ & $\mathrm{S}$ & $\mathrm{S}$ & $\mathrm{S}$ & $\mathrm{R}$ & $\mathrm{S}$ \\
\hline 13 & B-5177 & K. pneumoniae & --- & $\mathrm{R}$ & $\mathrm{R}$ & $\mathrm{R}$ & $\mathrm{R}$ & $\mathrm{S}$ & $\mathrm{S}$ & $\mathrm{S}$ & $\mathrm{S}$ & S \\
\hline 14 & B-5230 & P. mirabilis & --- & $\mathrm{R}$ & $\mathrm{R}$ & $\mathrm{R}$ & $\mathrm{R}$ & $\mathrm{S}$ & $\mathrm{S}$ & $\mathrm{R}$ & $\mathrm{S}$ & $\mathrm{R}$ \\
\hline 15 & B-5228 & Escherichia coli & --- & $\mathrm{S}$ & $\mathrm{R}$ & $\mathrm{R}$ & $\mathrm{R}$ & $\mathrm{S}$ & $\mathrm{S}$ & $\mathrm{S}$ & $\mathrm{R}$ & S \\
\hline 16 & B-5229 & Escherichia coli & --- & $\mathrm{S}$ & $\mathrm{S}$ & $\mathrm{S}$ & $\mathrm{S}$ & $\mathrm{S}$ & $\mathrm{S}$ & $\mathrm{S}$ & $\mathrm{R}$ & S \\
\hline 17 & B-5259 & K. pneumoniae & --- & I & $\mathrm{R}$ & $\mathrm{R}$ & I & $\mathrm{S}$ & $\mathrm{S}$ & $\mathrm{S}$ & $\mathrm{S}$ & S \\
\hline 18 & B-5230 (C8) & E. cloacae & NDM-1, OXA-48 & $\mathrm{R}$ & $\mathrm{R}$ & $\mathrm{R}$ & $\mathrm{R}$ & $\mathrm{R}$ & $\mathrm{R}$ & $\mathrm{R}$ & $\mathrm{S}$ & S \\
\hline 19 & B-1068 & Escherichia coli & -- & $\mathrm{R}$ & $\mathrm{R}$ & $\mathrm{R}$ & $\mathrm{R}$ & $\mathrm{S}$ & $\mathrm{S}$ & $\mathrm{S}$ & $\mathrm{R}$ & S \\
\hline 20 & B-1322 & K. pneumoniae & --- & $\mathrm{S}$ & $\mathrm{S}$ & $\mathrm{S}$ & $\mathrm{S}$ & $\mathrm{S}$ & $\mathrm{S}$ & $\mathrm{S}$ & $\mathrm{S}$ & S \\
\hline 21 & B-5100 & K. ornithinolytica & --- & $\mathrm{R}$ & $\mathrm{R}$ & I & $\mathrm{S}$ & $\mathrm{s}$ & $\mathrm{s}$ & $\mathrm{S}$ & $\mathrm{R}$ & S \\
\hline 22 & $\mathrm{~K}-1$ (C9) & Escherichia coli & NDM-1, OXA-48 & $\mathrm{R}$ & $\mathrm{R}$ & $\mathrm{R}$ & $\mathrm{R}$ & $\mathrm{R}$ & $\mathrm{R}$ & $\mathrm{S}$ & $\mathrm{R}$ & S \\
\hline 23 & $\mathrm{~K}-2$ & K. pneumoniae & --- & $\mathrm{S}$ & $\mathrm{S}$ & $\mathrm{S}$ & $\mathrm{S}$ & $\mathrm{S}$ & $\mathrm{S}$ & $\mathrm{S}$ & $\mathrm{S}$ & S \\
\hline 24 & $\mathrm{Z}-1$ & K. pneumoniae & --- & $\mathrm{S}$ & $\mathrm{S}$ & $\mathrm{S}$ & $\mathrm{S}$ & $\mathrm{S}$ & $\mathrm{S}$ & $\mathrm{S}$ & $\mathrm{S}$ & S \\
\hline 25 & $\mathrm{Z}-2 \mathrm{G}(\mathrm{C} 24)$ & Proteus mirabilis & NDM-1, OXA-48 & $\mathrm{R}$ & $\mathrm{R}$ & $\mathrm{R}$ & $\mathrm{R}$ & $\mathrm{R}$ & $\mathrm{R}$ & $\mathrm{S}$ & $\mathrm{R}$ & $\mathrm{R}$ \\
\hline 26 & $\mathrm{Z}-2 \mathrm{Y}$ & K. pneumoniae & -- & $\mathrm{R}$ & $\mathrm{R}$ & $\mathrm{R}$ & $\mathrm{R}$ & $\mathrm{S}$ & $\mathrm{S}$ & $\mathrm{R}$ & $\mathrm{R}$ & S \\
\hline 27 & $\mathrm{Z}-3$ & Escherichia coli & --- & $\mathrm{R}$ & $\mathrm{R}$ & $\mathrm{R}$ & $\mathrm{R}$ & $\mathrm{S}$ & $\mathrm{S}$ & $\mathrm{S}$ & I & S \\
\hline 28 & $\mathrm{Z}-4(\mathrm{C} 25)$ & K. pneumoniae & KPC, NDM-1, OXA-48 & $\mathrm{R}$ & $\mathrm{R}$ & $\mathrm{R}$ & $\mathrm{R}$ & $\mathrm{R}$ & $\mathrm{R}$ & $\mathrm{S}$ & $\mathrm{R}$ & $\mathrm{S}$ \\
\hline 29 & Z-6 & E. coli & -- & $\mathrm{S}$ & $\mathrm{S}$ & $\mathrm{S}$ & $\mathrm{S}$ & $\mathrm{S}$ & $\mathrm{S}$ & $\mathrm{S}$ & $\mathrm{S}$ & S \\
\hline 30 & $\mathrm{Z}-8$ & E. coli & --- & $\mathrm{R}$ & I & $\mathrm{S}$ & $\mathrm{S}$ & $\mathrm{S}$ & $\mathrm{S}$ & $\mathrm{S}$ & $\mathrm{S}$ & S \\
\hline 31 & Z-9 & E. coli & --- & $\mathrm{S}$ & $\mathrm{S}$ & $\mathrm{S}$ & $\mathrm{S}$ & $\mathrm{S}$ & $\mathrm{S}$ & $\mathrm{S}$ & $\mathrm{S}$ & S \\
\hline 32 & $\mathrm{Z}-10$ & E. coli & --- & $\mathrm{S}$ & $\mathrm{S}$ & $\mathrm{S}$ & $\mathrm{S}$ & $\mathrm{S}$ & $\mathrm{S}$ & $\mathrm{S}$ & $\mathrm{S}$ & S \\
\hline 33 & $\mathrm{Z}-11 \mathrm{Y}$ & K. pneumoniae & --- & $\mathrm{S}$ & $\mathrm{S}$ & $\mathrm{S}$ & $\mathrm{S}$ & $\mathrm{S}$ & $\mathrm{S}$ & $\mathrm{S}$ & $\mathrm{S}$ & S \\
\hline 34 & $\mathrm{Z}-11 \mathrm{G}$ & Proteus mirabilis & --- & $\mathrm{S}$ & $\mathrm{S}$ & $\mathrm{S}$ & $\mathrm{S}$ & $\mathrm{S}$ & $\mathrm{S}$ & $\mathrm{S}$ & $\mathrm{R}$ & $\mathrm{R}$ \\
\hline 35 & $\mathrm{Z}-12$ & K. pneumoniae & --- & $\mathrm{S}$ & $\mathrm{S}$ & $\mathrm{S}$ & $\mathrm{S}$ & $\mathrm{S}$ & $\mathrm{S}$ & $\mathrm{S}$ & $\mathrm{S}$ & S \\
\hline 36 & $\mathrm{Z}-13(\mathrm{C} 1)$ & K. pneumoniae & KPC, NDM-1, OXA-48 & $\mathrm{R}$ & $\mathrm{R}$ & $\mathrm{R}$ & $\mathrm{R}$ & $\mathrm{R}$ & $\mathrm{R}$ & $\mathrm{S}$ & $\mathrm{S}$ & S \\
\hline 37 & Z-17 & Citrobacter & --- & $\mathrm{S}$ & I & $\mathrm{R}$ & $\mathrm{S}$ & $\mathrm{S}$ & $\mathrm{S}$ & $\mathrm{R}$ & $\mathrm{S}$ & S \\
\hline 38 & $\mathrm{Z}-18$ & K. ornithinolytica & --- & $\mathrm{S}$ & $\mathrm{R}$ & $\mathrm{R}$ & $\mathrm{S}$ & $\mathrm{S}$ & $\mathrm{S}$ & $\mathrm{S}$ & $\mathrm{S}$ & $\mathrm{S}$ \\
\hline 39 & Z-19 & K. ornithinolytica & --- & $\mathrm{S}$ & $\mathrm{S}$ & $\mathrm{S}$ & $\mathrm{S}$ & $\mathrm{S}$ & $\mathrm{S}$ & $\mathrm{S}$ & $\mathrm{S}$ & S \\
\hline 40 & $\mathrm{Z}-21$ & E. coli & --- & $\mathrm{S}$ & $\mathrm{R}$ & $\mathrm{R}$ & $\mathrm{S}$ & $\mathrm{S}$ & $\mathrm{S}$ & $\mathrm{S}$ & $\mathrm{S}$ & S \\
\hline 41 & $\mathrm{Z}-23$ & Proteus mirabilis & --- & $\mathrm{R}$ & $\mathrm{R}$ & I & $\mathrm{S}$ & $\mathrm{S}$ & $\mathrm{S}$ & $\mathrm{S}$ & $\mathrm{R}$ & $\mathrm{R}$ \\
\hline 42 & $\mathrm{Z}-25$ & Citrobacter & --- & I & $\mathrm{R}$ & $\mathrm{R}$ & I & $\mathrm{S}$ & $\mathrm{S}$ & $\mathrm{S}$ & $\mathrm{S}$ & $\mathrm{S}$ \\
\hline 43 & $\mathrm{Z}-24$ & Proteus mirabilis & --- & $\mathrm{S}$ & $\mathrm{R}$ & $\mathrm{R}$ & I & $\mathrm{S}$ & $\mathrm{S}$ & $\mathrm{S}$ & $\mathrm{S}$ & $\mathrm{R}$ \\
\hline 44 & Z-26 & K. pneumoniae & --- & $\mathrm{S}$ & $\mathrm{S}$ & $\mathrm{S}$ & $\mathrm{S}$ & $\mathrm{S}$ & $\mathrm{S}$ & $\mathrm{S}$ & $\mathrm{R}$ & $\mathrm{S}$ \\
\hline 45 & $\mathrm{Z}-27(\mathrm{C} 22)$ & K. pneumoniae & KPC, NDM-1, OXA-48 & $\mathrm{R}$ & $\mathrm{R}$ & $\mathrm{R}$ & $\mathrm{R}$ & $\mathrm{R}$ & $\mathrm{R}$ & $\mathrm{S}$ & $\mathrm{S}$ & S \\
\hline 46 & $\mathrm{Z}-28$ & Proteus mirabilis & --- & $\mathrm{S}$ & $\mathrm{S}$ & $\mathrm{S}$ & $\mathrm{S}$ & $\mathrm{S}$ & $\mathrm{S}$ & $\mathrm{S}$ & $\mathrm{R}$ & $\mathrm{R}$ \\
\hline 47 & Z-29 & K. pneumoniae & --- & I & $\mathrm{R}$ & $\mathrm{R}$ & I & $\mathrm{S}$ & $\mathrm{S}$ & $\mathrm{S}$ & $\mathrm{S}$ & $\mathrm{S}$ \\
\hline 48 & $\mathrm{~F}-1$ & E.coli & --- & $\mathrm{R}$ & $\mathrm{R}$ & $\mathrm{R}$ & $\mathrm{R}$ & $\mathrm{S}$ & $\mathrm{S}$ & $\mathrm{S}$ & $\mathrm{S}$ & S \\
\hline 49 & $\mathrm{~F}-2(\mathrm{C} 10)$ & K. pneumoniae & KPC, NDM-1, OXA-48 & $\mathrm{R}$ & $\mathrm{R}$ & $\mathrm{R}$ & $\mathrm{R}$ & $\mathrm{R}$ & $\mathrm{R}$ & $\mathrm{R}$ & $\mathrm{R}$ & S \\
\hline 50 & F-3 & E. coli & -- & $\mathrm{S}$ & $\mathrm{S}$ & $\mathrm{S}$ & $\mathrm{S}$ & $\mathrm{S}$ & $\mathrm{S}$ & $\mathrm{S}$ & $\mathrm{R}$ & $\mathrm{S}$ \\
\hline 51 & F-4 & Serratia sp. & --- & $\mathrm{R}$ & $\mathrm{R}$ & $\mathrm{R}$ & $\mathrm{R}$ & $\mathrm{S}$ & $\mathrm{S}$ & I & $\mathrm{R}$ & $\mathrm{S}$ \\
\hline
\end{tabular}




\begin{tabular}{|c|c|c|c|c|c|c|c|c|c|c|c|c|}
\hline \multirow[b]{2}{*}{$\begin{array}{l}\text { S. } \\
\text { No }\end{array}$} & \multirow[b]{2}{*}{$\underset{* *}{\text { Hospital code No }}$} & \multirow[b]{2}{*}{ Organism } & \multirow[b]{2}{*}{ Carbapenemase genes } & \multicolumn{9}{|c|}{ Antibiotics } \\
\hline & & & & لْ & 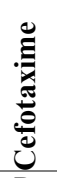 & 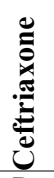 & 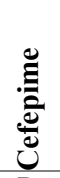 & 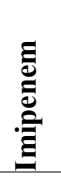 & 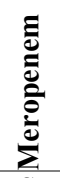 & 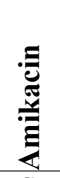 & 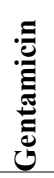 & 苞 \\
\hline 52 & F-5 & Serratia sp. & --- & $\mathrm{R}$ & $\mathrm{R}$ & $\mathrm{R}$ & $\mathrm{R}$ & $\overline{\mathrm{S}}$ & $\mathrm{S}$ & $\mathrm{S}$ & $\mathrm{S}$ & $\mathrm{S}$ \\
\hline 53 & F-7 & Serratia sp. & --- & $\mathrm{S}$ & $\mathrm{S}$ & $\mathrm{S}$ & $\mathrm{S}$ & $\mathrm{S}$ & $\mathrm{S}$ & $\mathrm{S}$ & $\mathrm{S}$ & $\mathrm{S}$ \\
\hline 54 & F-8 & Serratia sp. & --- & $\mathrm{R}$ & $\mathrm{R}$ & $\mathrm{R}$ & $\mathrm{R}$ & $\mathrm{S}$ & $\mathrm{S}$ & $\mathrm{S}$ & $\mathrm{R}$ & $\mathrm{S}$ \\
\hline 55 & F-9 & K. oxytoca & --- & I & $\mathrm{R}$ & $\mathrm{R}$ & I & $\mathrm{S}$ & $\mathrm{S}$ & $\mathrm{S}$ & $\mathrm{S}$ & $\mathrm{S}$ \\
\hline 56 & $\mathrm{~F}-10$ & Serratia sp. & --- & $\mathrm{S}$ & $\mathrm{S}$ & $\mathrm{S}$ & $\mathrm{S}$ & $\mathrm{S}$ & $\mathrm{S}$ & S & $\mathrm{S}$ & $\mathrm{S}$ \\
\hline 57 & F-11 (C11) & K. pneumoniae & KPC, NDM-1, OXA-48 & $\mathrm{R}$ & $\mathrm{R}$ & $\mathrm{R}$ & $\mathrm{R}$ & $\mathrm{R}$ & $\mathrm{R}$ & $\mathrm{R}$ & $\mathrm{R}$ & $\mathrm{S}$ \\
\hline 58 & $\mathrm{~F}-12(\mathrm{C} 12)$ & K. pneumoniae & NDM-1, OXA-48 & $\mathrm{R}$ & $\mathrm{R}$ & $\mathrm{R}$ & $\mathrm{R}$ & $\mathrm{R}$ & $\mathrm{R}$ & $\mathrm{R}$ & $\mathrm{R}$ & $\mathrm{S}$ \\
\hline 59 & F-13 & R. ornithinolytica & -- & $\mathrm{R}$ & $\mathrm{R}$ & $\mathrm{R}$ & $\mathrm{R}$ & $\mathrm{S}$ & $\mathrm{S}$ & $\mathrm{S}$ & $\mathrm{S}$ & $\mathrm{S}$ \\
\hline 60 & F-14 & Citrobacter & --- & $\mathrm{S}$ & $\mathrm{R}$ & $\mathrm{R}$ & $\mathrm{S}$ & $\mathrm{S}$ & $\mathrm{S}$ & $\mathrm{S}$ & $\mathrm{R}$ & $\mathrm{S}$ \\
\hline 61 & $\mathrm{~F}-15$ & K. pneumoniae & --- & $\mathrm{R}$ & $\mathrm{R}$ & $\mathrm{R}$ & $\mathrm{R}$ & $\mathrm{S}$ & $\mathrm{S}$ & $\mathrm{S}$ & $\mathrm{S}$ & $\mathrm{S}$ \\
\hline 62 & $\mathrm{~F}-16(\mathrm{C} 13)$ & K. pneumoniae & KPC, NDM-1, OXA-48 & $\mathrm{R}$ & $\mathrm{R}$ & $\mathrm{R}$ & $\mathrm{R}$ & $\mathrm{R}$ & $\mathrm{R}$ & $\mathrm{R}$ & $\mathrm{R}$ & $\mathrm{S}$ \\
\hline 63 & $\mathrm{~F}-17(\mathrm{C} 14)$ & K. pneumoniae & KPC, NDM-1, OXA-48 & $\mathrm{R}$ & $\mathrm{R}$ & $\mathrm{R}$ & $\mathrm{R}$ & $\mathrm{R}$ & $\mathrm{R}$ & $\mathrm{R}$ & $\mathrm{R}$ & $\mathrm{S}$ \\
\hline 64 & F-18 & K. oxytoca & - & $\mathrm{S}$ & $\mathrm{R}$ & $\mathrm{I}$ & $\mathrm{S}$ & $\mathrm{S}$ & $\mathrm{S}$ & $\mathrm{S}$ & $\mathrm{S}$ & $\mathrm{S}$ \\
\hline 65 & F-19 & K. oxytoca & --- & $\mathrm{R}$ & $\mathrm{R}$ & $\mathrm{R}$ & $\mathrm{R}$ & $\mathrm{S}$ & $\mathrm{S}$ & $\mathrm{S}$ & $\mathrm{R}$ & $\mathrm{S}$ \\
\hline 66 & $\mathrm{~F}-20(\mathrm{C} 15)$ & K. pneumoniae & KPC, NDM-1, OXA-48 & $\mathrm{R}$ & $\mathrm{R}$ & $\mathrm{R}$ & $\mathrm{R}$ & $\mathrm{R}$ & $\mathrm{R}$ & $\mathrm{R}$ & $\mathrm{R}$ & $\mathrm{S}$ \\
\hline 67 & $\mathrm{~F}-21$ & K. oxytoca & --- & $\mathrm{R}$ & $\mathrm{R}$ & $\mathrm{R}$ & $\mathrm{R}$ & $\mathrm{S}$ & $\mathrm{S}$ & $\mathrm{S}$ & $\mathrm{R}$ & $\mathrm{S}$ \\
\hline 68 & $\mathrm{~F}-22$ & S. liquefaciens & --- & $\mathrm{R}$ & $\mathrm{R}$ & $\mathrm{S}$ & $\mathrm{R}$ & $\mathrm{S}$ & $\mathrm{S}$ & $\mathrm{S}$ & $\mathrm{S}$ & $\mathrm{S}$ \\
\hline 69 & $\mathrm{~F}-23$ & E. coli & --- & $\mathrm{R}$ & $\mathrm{R}$ & $\mathrm{R}$ & $\mathrm{R}$ & $\mathrm{S}$ & $\mathrm{S}$ & $\mathrm{S}$ & $\mathrm{S}$ & $\mathrm{S}$ \\
\hline 70 & $\mathrm{~F}-24$ & E. coli & --- & I & $\mathrm{R}$ & $\mathrm{R}$ & I & $\mathrm{S}$ & $\mathrm{S}$ & $\mathrm{S}$ & $\mathrm{R}$ & $\mathrm{S}$ \\
\hline 71 & $\mathrm{~F}-26(\mathrm{C} 16)$ & K. pneumoniae & KPC, NDM-1, OXA-48 & $\mathrm{R}$ & $\mathrm{R}$ & $\mathrm{R}$ & $\mathrm{R}$ & $\mathrm{R}$ & $\mathrm{R}$ & $\mathrm{R}$ & $\mathrm{R}$ & $\mathrm{S}$ \\
\hline 72 & $\mathrm{~F}-27(\mathrm{C} 17)$ & K. pneumoniae & KPC, NDM-1, OXA-48 & $\mathrm{R}$ & $\mathrm{R}$ & $\mathrm{R}$ & $\mathrm{R}$ & $\mathrm{R}$ & $\mathrm{R}$ & $\mathrm{R}$ & $\mathrm{R}$ & $\mathrm{S}$ \\
\hline 73 & F-28 & K. pneumoniae & -- & I & $\mathrm{R}$ & $\mathrm{R}$ & $\mathrm{S}$ & $\mathrm{S}$ & $\mathrm{S}$ & $\mathrm{S}$ & $\mathrm{S}$ & $\mathrm{S}$ \\
\hline 74 & F-29 & E. coli & --- & $\mathrm{S}$ & $\mathrm{S}$ & $\mathrm{S}$ & $\mathrm{S}$ & $\mathrm{S}$ & $\mathrm{S}$ & $\mathrm{S}$ & $\mathrm{S}$ & $\mathrm{S}$ \\
\hline 75 & $\mathrm{~F}-30$ & E. coli & --- & $\mathrm{S}$ & $\mathrm{S}$ & $\mathrm{S}$ & $\mathrm{S}$ & $\mathrm{S}$ & $\mathrm{S}$ & $\mathrm{S}$ & $\mathrm{S}$ & $\mathrm{S}$ \\
\hline 76 & $\mathrm{~F}-31(\mathrm{C} 18)$ & K. pneumoniae & KPC, NDM-1, OXA-48 & $\mathrm{R}$ & $\mathrm{R}$ & $\mathrm{R}$ & $\mathrm{R}$ & $\mathrm{R}$ & $\mathrm{R}$ & $\mathrm{R}$ & $\mathrm{R}$ & $\mathrm{S}$ \\
\hline 77 & F-32 & E. coli & --- & $\mathrm{S}$ & $\mathrm{R}$ & $\mathrm{R}$ & $\mathrm{S}$ & $\mathrm{S}$ & $\mathrm{S}$ & $\mathrm{S}$ & $\mathrm{R}$ & $\mathrm{S}$ \\
\hline 78 & F-33 & E. coli & --- & $\mathrm{S}$ & $\mathrm{R}$ & $\mathrm{R}$ & $\mathrm{S}$ & $\mathrm{S}$ & $\mathrm{S}$ & $\mathrm{S}$ & $\mathrm{S}$ & $\mathrm{S}$ \\
\hline 79 & $\mathrm{~F}-34(\mathrm{C} 19)$ & K. pneumoniae & KPC, NDM-1, OXA-48 & $\mathrm{R}$ & $\mathrm{R}$ & $\mathrm{R}$ & $\mathrm{R}$ & $\mathrm{R}$ & $\mathrm{R}$ & $\mathrm{S}$ & $\mathrm{R}$ & $\mathrm{S}$ \\
\hline 80 & F-35 & K. pneumoniae & -- & $\mathrm{S}$ & $\mathrm{S}$ & $\mathrm{S}$ & $\mathrm{S}$ & $\mathrm{S}$ & $\mathrm{S}$ & $\mathrm{S}$ & $\mathrm{S}$ & $\mathrm{S}$ \\
\hline 81 & F-36 & Citrobacter & --- & $\mathrm{S}$ & $\mathrm{R}$ & $\mathrm{R}$ & $\mathrm{S}$ & $\mathrm{S}$ & $\mathrm{S}$ & $\mathrm{S}$ & $\mathrm{R}$ & $\mathrm{S}$ \\
\hline 82 & F-37 & K. pneumoniae & --- & $\mathrm{R}$ & $\mathrm{R}$ & $\mathrm{R}$ & $\mathrm{R}$ & $\mathrm{S}$ & $\mathrm{S}$ & $\mathrm{S}$ & $\mathrm{R}$ & $\mathrm{S}$ \\
\hline 83 & $\mathrm{~F}-40$ & K. pneumoniae & --- & $\mathrm{S}$ & $\mathrm{S}$ & $\mathrm{S}$ & $\mathrm{S}$ & $\mathrm{S}$ & $\mathrm{S}$ & $\mathrm{S}$ & $\mathrm{S}$ & $\mathrm{S}$ \\
\hline 84 & F-41 & K. pneumoniae & --- & $\mathrm{R}$ & $\mathrm{R}$ & $\mathrm{R}$ & $\mathrm{R}$ & $\mathrm{S}$ & $\mathrm{S}$ & $\mathrm{S}$ & $\mathrm{S}$ & $\mathrm{S}$ \\
\hline 85 & $\mathrm{~F}-42(\mathrm{C} 20)$ & K. pneumoniae & KPC, NDM-1, OXA-48 & $\mathrm{R}$ & $\mathrm{R}$ & $\mathrm{R}$ & $\mathrm{R}$ & $\mathrm{R}$ & $\mathrm{R}$ & $\mathrm{S}$ & $\mathrm{R}$ & $\mathrm{S}$ \\
\hline 86 & F-43 & E. coli & -- & $\mathrm{R}$ & $\mathrm{R}$ & $\mathrm{R}$ & $\mathrm{R}$ & $\mathrm{S}$ & $\mathrm{S}$ & $\mathrm{S}$ & $\mathrm{S}$ & $\mathrm{S}$ \\
\hline 87 & $\mathrm{MCH}-1275(\mathrm{C} 2)$ & K. pneumoniae & KPC, NDM-1, OXA-48 & $\mathrm{R}$ & $\mathrm{R}$ & $\mathrm{R}$ & $\mathrm{R}$ & $\mathrm{R}$ & $\mathrm{R}$ & $\mathrm{S}$ & $\mathrm{R}$ & $\mathrm{S}$ \\
\hline 88 & MCH-1299 & Escherichia coli & -- & $\mathrm{R}$ & $\mathrm{R}$ & $\mathrm{R}$ & $\mathrm{R}$ & $\mathrm{S}$ & $\mathrm{S}$ & $\mathrm{S}$ & $\mathrm{S}$ & $\mathrm{S}$ \\
\hline 89 & MCH-1288 & Escherichia coli & --- & $\mathrm{S}$ & $\mathrm{S}$ & $\mathrm{S}$ & $\mathrm{S}$ & $\mathrm{S}$ & $\mathrm{S}$ & $\mathrm{S}$ & $\mathrm{S}$ & $\mathrm{S}$ \\
\hline 90 & MCH-664BC & Escherichia coli & --- & $\mathrm{S}$ & $\mathrm{S}$ & $\mathrm{S}$ & $\mathrm{S}$ & $\mathrm{S}$ & $\mathrm{S}$ & $\mathrm{S}$ & $\mathrm{S}$ & $\mathrm{S}$ \\
\hline 91 & MCH-1241 & Escherichia coli & --- & $\mathrm{S}$ & $\mathrm{S}$ & $\mathrm{S}$ & $\mathrm{S}$ & $\mathrm{S}$ & $\mathrm{S}$ & $\mathrm{S}$ & $\mathrm{S}$ & $\mathrm{S}$ \\
\hline 92 & MCH-1264 & Escherichia coli & --- & $\mathrm{S}$ & $\mathrm{S}$ & $\mathrm{S}$ & $\mathrm{S}$ & $\mathrm{S}$ & $\mathrm{S}$ & $\mathrm{S}$ & $\mathrm{S}$ & $\mathrm{S}$ \\
\hline 93 & MCH-109 & K. oxytoca & --- & $\mathrm{R}$ & $\mathrm{S}$ & I & $\mathrm{R}$ & $\mathrm{S}$ & $\mathrm{S}$ & $\mathrm{S}$ & $\mathrm{S}$ & $\mathrm{S}$ \\
\hline 94 & MCH-123 & Escherichia coli & --- & $\mathrm{R}$ & $\mathrm{R}$ & $\mathrm{R}$ & I & $\mathrm{S}$ & $\mathrm{S}$ & $\mathrm{S}$ & $\mathrm{R}$ & $\mathrm{S}$ \\
\hline 95 & MCH-1318 & Salmonella & --- & $\mathrm{S}$ & $\mathrm{S}$ & $\mathrm{S}$ & $\mathrm{S}$ & $\mathrm{S}$ & $\mathrm{S}$ & $\mathrm{S}$ & $\mathrm{S}$ & $\mathrm{S}$ \\
\hline 96 & MCH-272 & Escherichia coli & --- & $\mathrm{S}$ & $\mathrm{S}$ & $\mathrm{S}$ & $\mathrm{S}$ & $\mathrm{S}$ & $\mathrm{S}$ & $\mathrm{S}$ & $\mathrm{S}$ & $\mathrm{S}$ \\
\hline 97 & MCH-279 & Escherichia coli & --- & $\mathrm{S}$ & $\mathrm{S}$ & $\mathrm{S}$ & $\mathrm{S}$ & $\mathrm{S}$ & $\mathrm{S}$ & $\mathrm{S}$ & $\mathrm{S}$ & $\mathrm{S}$ \\
\hline 98 & MCH-429 & Escherichia coli & --- & $\mathrm{S}$ & $\mathrm{S}$ & $\mathrm{S}$ & $\mathrm{S}$ & $\mathrm{S}$ & $\mathrm{S}$ & $\mathrm{S}$ & $\mathrm{S}$ & $\mathrm{S}$ \\
\hline 99 & $\mathrm{MCH}-440$ & Escherichia coli & --- & $\mathrm{S}$ & $\mathrm{S}$ & $\mathrm{S}$ & $\mathrm{S}$ & $\mathrm{S}$ & $\mathrm{S}$ & $\mathrm{S}$ & $\mathrm{S}$ & $\mathrm{S}$ \\
\hline 100 & MCH-455 & Escherichia coli & --- & $\mathrm{S}$ & $\mathrm{S}$ & $\mathrm{R}$ & $\mathrm{S}$ & $\mathrm{S}$ & $\mathrm{S}$ & $\mathrm{S}$ & $\mathrm{R}$ & $\mathrm{S}$ \\
\hline 101 & MCH-378 & Escherichia coli & --- & $\mathrm{S}$ & $\mathrm{S}$ & $\mathrm{R}$ & $\mathrm{R}$ & $\mathrm{S}$ & $\mathrm{S}$ & $\mathrm{S}$ & $\mathrm{R}$ & $\mathrm{S}$ \\
\hline 102 & MCH-482 & Escherichia coli & --- & $\mathrm{S}$ & $\mathrm{S}$ & $\mathrm{S}$ & $\mathrm{S}$ & $\mathrm{S}$ & $\mathrm{S}$ & $\mathrm{S}$ & $\mathrm{R}$ & $\mathrm{S}$ \\
\hline 103 & MCH-494 & Escherichia coli & --- & $\mathrm{S}$ & $\mathrm{S}$ & $\mathrm{R}$ & $\mathrm{S}$ & $\mathrm{S}$ & $\mathrm{S}$ & $\mathrm{S}$ & $\mathrm{S}$ & $\mathrm{S}$ \\
\hline
\end{tabular}




\begin{tabular}{|c|c|c|c|c|c|c|c|c|c|c|c|c|}
\hline \multirow[b]{2}{*}{$\begin{array}{l}\text { S. } \\
\text { No }\end{array}$} & \multirow[b]{2}{*}{$\underset{* *}{\text { Hospital code No }}$} & \multirow[b]{2}{*}{ Organism } & \multirow[b]{2}{*}{ Carbapenemase genes } & \multicolumn{9}{|c|}{ Antibiotics } \\
\hline & & & & 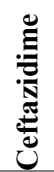 & 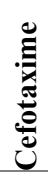 & 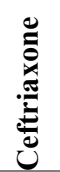 & 巳: & 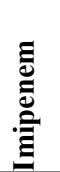 & 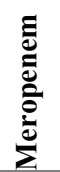 & 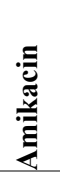 & 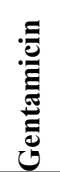 & 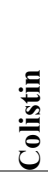 \\
\hline 104 & MCH-723(C21) & Escherichia coli & OXA-48 & $\mathrm{R}$ & $\mathrm{R}$ & $\mathrm{R}$ & $\mathrm{R}$ & $\overline{\mathrm{R}}$ & $\mathrm{R}$ & $\mathrm{S}$ & $\mathrm{R}$ & $\mathrm{S}$ \\
\hline 105 & MCH-163 (C23) & K. pneumoniae & KPC, OXA-48 & $\mathrm{R}$ & $\mathrm{R}$ & $\mathrm{R}$ & $\mathrm{R}$ & $\mathrm{R}$ & $\mathrm{R}$ & $\mathrm{R}$ & $\mathrm{R}$ & S \\
\hline 106 & G-1 & Salmonella sp. & ---- & $\mathrm{S}$ & $\mathrm{S}$ & $\mathrm{S}$ & $\mathrm{S}$ & $\mathrm{S}$ & $\mathrm{S}$ & $\mathrm{S}$ & $\mathrm{S}$ & $\mathrm{S}$ \\
\hline 107 & G-2 & E. coli & ---- & $\mathrm{S}$ & $\mathrm{R}$ & $\mathrm{S}$ & $\mathrm{R}$ & $\mathrm{S}$ & $\mathrm{S}$ & $\mathrm{S}$ & $\mathrm{R}$ & $\mathrm{S}$ \\
\hline 108 & G-4 & E. aerogenes & ---- & $\mathrm{S}$ & $\mathrm{S}$ & $\mathrm{S}$ & $\mathrm{S}$ & $\mathrm{S}$ & $\mathrm{S}$ & $\mathrm{S}$ & $\mathrm{R}$ & $\mathrm{S}$ \\
\hline 109 & G-5 & S. liquefaciens & ---- & $\mathrm{R}$ & $\mathrm{R}$ & $\mathrm{R}$ & $\mathrm{S}$ & $\mathrm{S}$ & $\mathrm{S}$ & $\mathrm{S}$ & $\mathrm{S}$ & S \\
\hline 110 & G-6 & E. coli & ---- & $\mathrm{S}$ & $\mathrm{S}$ & $\mathrm{S}$ & $\mathrm{S}$ & $\mathrm{S}$ & $\mathrm{S}$ & $\mathrm{S}$ & $\mathrm{R}$ & $\mathrm{S}$ \\
\hline 111 & G-7 & K. ornithinolytica & ---- & $\mathrm{S}$ & $\mathrm{S}$ & $\mathrm{S}$ & $\mathrm{S}$ & $\mathrm{S}$ & $\mathrm{S}$ & $\mathrm{S}$ & $\mathrm{S}$ & $\mathrm{S}$ \\
\hline 112 & G-8 & K. pneumoniae & ---- & $\mathrm{S}$ & $\mathrm{S}$ & $\mathrm{S}$ & $\mathrm{S}$ & $\mathrm{S}$ & $\mathrm{S}$ & $\mathrm{S}$ & $\mathrm{S}$ & S \\
\hline 113 & G-10 & E. coli & ---- & $\mathrm{S}$ & $\mathrm{R}$ & $\mathrm{R}$ & I & $\mathrm{S}$ & $\mathrm{S}$ & $\mathrm{S}$ & $\mathrm{R}$ & $\mathrm{S}$ \\
\hline 114 & G-11 & K. ornithinolytica & ---- & $\mathrm{S}$ & $\mathrm{S}$ & $\mathrm{S}$ & $\mathrm{S}$ & $\mathrm{S}$ & $\mathrm{S}$ & $\mathrm{S}$ & $\mathrm{R}$ & $\mathrm{S}$ \\
\hline 115 & G-12 & E. cloacae & ---- & $\mathrm{S}$ & $\mathrm{S}$ & $\mathrm{S}$ & $\mathrm{S}$ & $\mathrm{S}$ & $\mathrm{S}$ & $\mathrm{S}$ & $\mathrm{S}$ & $\mathrm{S}$ \\
\hline 116 & G-13 & K. pneumoniae & ---- & $\mathrm{R}$ & $\mathrm{R}$ & $\mathrm{R}$ & I & $\mathrm{S}$ & $\mathrm{S}$ & $\mathrm{S}$ & $\mathrm{S}$ & $\mathrm{S}$ \\
\hline 117 & G-14 & K. pneumoniae & ---- & $\mathrm{R}$ & $\mathrm{R}$ & $\mathrm{R}$ & $\mathrm{S}$ & $\mathrm{S}$ & $\mathrm{S}$ & $\mathrm{S}$ & $\mathrm{R}$ & S \\
\hline 118 & G-15 & K. pneumoniae & ---- & $\mathrm{R}$ & $\mathrm{R}$ & $\mathrm{R}$ & $\mathrm{R}$ & $\mathrm{S}$ & $\mathrm{S}$ & $\mathrm{S}$ & $\mathrm{S}$ & $\mathrm{S}$ \\
\hline 119 & G-17 & Salmonella sp. & ---- & $\mathrm{S}$ & $\mathrm{S}$ & $\mathrm{S}$ & $\mathrm{S}$ & $\mathrm{S}$ & $\mathrm{S}$ & $\mathrm{S}$ & $\mathrm{R}$ & $\mathrm{S}$ \\
\hline 120 & G-18 & E. coli & ---- & $\mathrm{S}$ & $\mathrm{S}$ & $\mathrm{S}$ & $\mathrm{S}$ & $\mathrm{S}$ & $\mathrm{S}$ & $\mathrm{S}$ & $\mathrm{R}$ & $\mathrm{S}$ \\
\hline
\end{tabular}

** Hospital code key: B \& K = Al-Noor Specialized hospital ( $\mathrm{n}=23) ; \mathrm{Z}=$ King Abdul Aziz Hospital $(\mathrm{n}=24)$; F = King Faisal Hospital ( $=$ = 39); MCH \& G = Maternity and Children Hospital $(\mathrm{n}=34)$

Supplementary Table 4. Distribution of Klebsiella penumoniae isolates carrying triple genes in relation to hospitals/wards.

\begin{tabular}{lccccc}
\hline \multirow{2}{*}{ Hospitals } & \multicolumn{4}{c}{ Klebsiella penumoniae isolates with triple genes } \\
\cline { 2 - 6 } & $\begin{array}{c}\text { Intensive care } \\
\text { unit }\end{array}$ & Medical ward & Surgical ward & Pediatric ward & Total \\
\hline King Faisal hospital & 5 & 2 & 2 & 1 & 10 \\
Maternity and children hospital & 0 & 1 & 0 & 0 & 1 \\
Al-Noor specialist hospital & 2 & 1 & 0 & 0 & 3 \\
King Abdul Aziz hospital & 2 & 1 & 0 & 0 & 3 \\
Total & 9 & 5 & 2 & 1 & 17 \\
\hline
\end{tabular}

